\title{
The Development Strategy Of Coastal Area In Makassar City Through Governance System Analysis (GSA) Framework
}

\author{
Handam $^{1,2}$, Andi Luhur Prianto ${ }^{2}$, Zulfan Nahruddin ${ }^{2}$ \\ \{handam@unismuh.ac.id ${ }^{1}$ \} \\ Universitas Padjadjaran ${ }^{1}$ \\ Universitas Muhammadiyah Makassar ${ }^{2}$
}

\begin{abstract}
This study aims to analyze the development strategy of the coastal area in Makassar city through the framework of Governance System Analysis (GSA). This study used a qualitative approach with descriptive research. It based on the actual data source on the interview. Activities in the data analysis were data reduction, data display, and conclusion drawing/verification. The result showed the planning process was carried out with the arrangement of a mature regional sectoral development program it cannot separate from development policies that have been implemented in the Medium-Term Development Plan (RPJM) and Long-Term Development Plan (RPJP). The connectivity in the preservation of coastal environment areas of Makassar city either in society or international organizations should be cooperated in preserving the environment especially the planting of mangroves in the coastal areas. In the knowledge aspect, the preparation of public consultation is for program development of coastal areas. Through public consultation mechanisms with social participation could adapt to public input and the stages of planning activities in coastal areas.
\end{abstract}

Keywords: Coastal Regions, City, Strategy, GSA.

\section{Introduction}

The process of developing a region that is not well planned will cause the tourist area to reach a phase of stagnation in a short period of time [1]. Indonesia is an archipelago rich in natural resources. This situation has caused the coastal area to become a mainstay of Indonesian people's income sources. Considering Indonesia's coastal natural strategic conditions have different regional characteristics, the utilization of coastal resources optimally and sustainably can only be realized if the management is carried out in an integrated manner, applying the principles of sustainable development and the development approach carried out organized across sectors [2]. Government policies that provide opportunities for coastal communities or stakeholders of coastal resource users in the involvement of sustainable coastal and ocean resources through an integrated approach to avoid conflicts over spatial use that often occur in coastal areas [3], [4].

Coastal development has similarities with regional development in other regions, only the difference lies in its main objective is to improve the welfare of coastal communities, especially those working in the fisheries sector [5]. The development of strategies is needed to develop regional potential. by maximizing its governance [6]. Coastal areas are basically the 
boundaries between sea and land areas that influence and are influenced by each other from the ecological aspect [7], and socio-economics in providing services and utilizing natural resources for coastal communities, especially those working in the fisheries and home industry sectors.

The actual situation that still occurs based on observations is still encountered with classic problems such as limited sources of management funds, low quality of human resources, poverty of coastal communities, lack of coordination between development actors. To overcome problems in the utilization of coastal areas, the principle of integrated spatial planning is needed, including coastal and oceanic spatial planning. Therefore the determination of the Governance Systems Analysis (GSA) framework is an interesting discussion to be elaborated from a scientific context.

This is related to a number of governance literature that emerged from the literature of policy analysis, environmental science and corporate governance [8]. The combination of these components is relevant to the object of this study that discusses the development of the strategy of the coastal city of Makassar, where researchers can review from the perspective of Governance Systems Analysis theory [9] in which there are specific variables about the development of strategies that show linkages with aspects of capacity taking decision, connectivity and use of knowledge.

The objects specifically traced in this study are clearly legitimated in the regulation, namely the Regional Regulation No. 4 of 2015 concerning the 2015-2034 Makassar City Spatial Plan where there are planned, measurable, development strategies for the western and northern coastal areas of the city. limited, and limited. This research explores using the development strategy aspect within the Governance Systems Analysis (GSA) framework. Through the GSA concept, this research describes the development of the strategy of the Makassar city coastal area from the aspect of Decision Making Capacity, Connectivity and Use of Knowledge.

\section{Methodology}

This study uses a qualitative approach with the type of descriptive research used to describe in detail about the circumstances or events described in real terms related to the object under study, namely the development of the Makassar city coastal area which is binocular researchers through the Governance Systems Analysis (GSA) framework. This research is located in the Makassar City Spatial and Building Agency and the Makassar City Regional Development Planning Agency, with the consideration that it is necessary to conduct research to find out in actual terms based on the results of the interviews. The technique of collecting informants used was a purposive sampling of people who were able to provide information about the situation and background conditions of the study. To facilitate the determination of informants in the field, researchers target key informants are the Head of Service and the head of the field in the Makassar City Spatial and Building Office. Activities in data analysis, namely data reduction, data display, and conclusion drawing/verification. Development of the strategy of the Makassar city coastal area through the Governance Systems Analysis (GSA) framework which consists of Decision Making Capacity, Connectivity and Use of Knowledge.

\section{Result and Discussion}

To find out the development of the strategy of the Makassar city coastal area through the Governance Systems Analysis (GSA) framework, this research emphasizes the development 
of the strategy of the coastal city of Makassar, which researchers can review from the perspective of Governance Systems Analysis theory (Potts \& Vella, 2015) in which there are variables specific about developing strategies related to indicators of decision-making capacity, connectivity, and use of knowledge.

\subsection{Decision-Making Capacity}

To provide an explanation of organizational capacity in order to establish clear strategic targets. Based on the results of the interview, it can be seen that there are various types of agencies that play a role in the North Makassar reclamation area, including the Ministry of Agrarian and Spatial Planning, Ministry of Public Works and Public Housing, City Government, Private Sector, and the public. Office of PSDA, Cipta Karya and Spatial Planning of South Sulawesi Province, and Regional Development Planning Agency (Bappeda) of South Sulawesi Province.

Decision-Making Capacity also sees stakeholders who have the knowledge, financial, human and infrastructure resources available to make the necessary decisions. Based on the interview results it can be seen that there is a basis for planning that is outlined in the 20152034 RTRW of Makassar City in which it outlines the objectives of urban spatial planning. The key institution involved in having strong organizational governance is the Regional Development Planning Agency (Bappeda) because it can make planning directed and systematic through the long-term and medium-term plans.

Based on the results of the interview the planning process has been done carefully the arrangement of regional sectoral development programs is inseparable from the development policies that have been announced in the Medium-Term Development Plan (RPJM) and the Long-Term Development Plan (RPJP). Furthermore, in terms of budget, there is funding from the Ministry of Maritime Affairs and Fisheries (KKP) which prepares the budget allocated for the improvement of the Nusantara Port Untia Makassar infrastructure, management of the budget until the physical auction process is carried out by the ministry.

The capacity of an organization that understands planning in its entirety has been well prepared and in accordance with the direction of controlling the utilization of urban space. The existence of the RTRW that has been made with the Regional Planning Agency (Bappeda) can be used as a guideline for the implementation of development by utilizing space for development activities in the Makassar City area. In order for spatial utilization within the period of time the plan is valid in accordance with the spatial plan, it is necessary to control the use of space such as the coastal area of Makassar City.

\subsection{Connectivity}

Every strategy implementation needs to maximize connectivity so that planning in a program can be realized properly. Based on the results of connectivity interviews aimed at both the main long-term programs whose actualization will be specified in the city's five-year midterm program which includes indications of the main program, funding sources, implementing agencies, construction sites, and implementation time structured in the program's manifestation plan an indication of the program embodies the plan for the urban spatial pattern, and an indication of the program realization of the strategic area. In the implementation of development, the main plan is prioritized in certain areas in meeting the needs of the people of Makassar City.

Based on the results of the interview, it can be seen that the water catchment area needs protection to provide free space for the absorption of rainwater in certain areas to provide 
groundwater needs and flood mitigation. In addition, it can be seen that there has been a significant increase in the use of vacant land for several years. This condition certainly has the potential to affect the depreciation or reduced area of water catchment centers in the Makassar City Region. The water catchment area in Makassar City is in the Balang Tonjong Lake Area in Manggala Subdistrict whose priority is now to become the main area. Although seen from the segment the role of the area is aimed at the water catchment area that can be optimized.

The findings of this study are the segmentation of coastal border areas in the city of Makassar, namely the area of mangrove forests whose objects are located in the northern sea coastal area or Untia Beach, this area is a natural habitat for mangroves which is useful to provide protection for the natural life of the ocean. Based on the data of mangrove forests located at the mouth of the river is a tidal area or the edge of the sea.

The direction of planning the coastal border area which is designated as a protected area is on the edge of the coast which stretches from the northern coastal area of the city to the western coastal areas of the city in Biringkanaya Subdistrict, Tamalanrea District, Tallo District, Ujung Tanah District, Ujung Pandang District, Wajo District, Mariso District, Tamalate District, and Sangkarrang Islands District. The beach border which is still natural and does not occur degradation is carried out by utilizing policies that certainly can conserve the area.

Connectivity is also reflected in the efforts or carried out by maintaining special coastal areas in the Untia area and also the beaches around Losari Bay.

Based on the results of the interview, it can be seen that there is connectivity in the effort to preserve the environment in the coastal city of Makassar, both the community and international institutions that collaborate in preserving the environment, especially the planting of mangroves in the coastal area of Untia. The Action Plan Matrix is related to the strategy of controlling coastal and marine areas. Based on the interviews, it can be seen that connectivity in the conservation of coastal areas is carried out in various ways, namely through the construction of breakwaters to coastal areas accompanied by reforestation through planting mangroves around the Tanjung Bunga beach area which can reduce the degree of coastal abrasion and subsequent efforts are to make artificial reef activities. as an effort to rehabilitate the marine environment.

In the RTRW document, environmental conditions are explained, river boundaries are defined along the corridors of the Jeneberang River, Tallo River, and rivers within the Makassar City area. For existing conditions, the Tallo River has been heavily degraded. In general, the area around the border of this river has been converted into a residential area and business area, so the border space is increasingly narrow. The transfer of the function of the area is what causes environmental inconsistencies because there have been many human interventions in it. It is different with the Jeneberang river which has environmental balance control. Along the Jeneberang border corridor can be found the use of land as an object of land use with the planting of ornamental plants.

Through a series of research results found that the Collaborative Framework for goal setting designed to involve each party and the coastal area development strategy integrates all problems with long-term solutions, this can be seen from the connectivity in environmental conservation efforts in the coastal city of Makassar, both communities and institutions international cooperation. Connectivity is also aimed at both the long-term main programs whose actualization will be specified in the city's five-year midterm program which includes indications of the main program, funding sources, implementing agencies, construction sites, and the implementation time structured in the program indication embodiment of the structural 
plan, program indication realization of plans for urban spatial patterns, and indications of program realization of strategic areas.

In the RTRW document, the condition of the river boundary is explained along the corridors of the Jeneberang River, Tallo River, and the rivers in the Makassar City area. For existing conditions, the Tallo River has been heavily degraded. In general, the area around the border of this river has been converted into a residential area and business area, so the border space is increasingly narrow. The transfer of the function of the area is what causes environmental inconsistencies, because there have been many human interventions in it.

It is different with the Jeneberang river which has environmental balance control. Along the Jeneberang border corridor can be found the use of land as an object of land use with the planting of ornamental plants. Through a series of research results found that the Collaborative Framework for goal setting designed to involve each party and the coastal area development strategy integrate all problems with long-term solutions, this can be seen from the connectivity in environmental conservation efforts in the coastal city of Makassar, both communities and institutions international cooperation.

Connectivity is also aimed at both the long-term main programs whose actualization will be specified in the city's five-year midterm program which includes indications of the main program, funding sources, implementing agencies, construction sites, and the implementation time structured in the program indication embodiment of the structural plan, program indication realization of plans for urban spatial patterns, and indications of program realization of strategic areas.

\subsection{Use of knowledge}

The description of the use of this knowledge needs the support of information about the knowledge disseminated to the public about coastal area management, based on the results of the interview it can be seen that there is a concept of Integrated Coastal and Marine Planning and Management (ICZPM) which provides guidance for the provincial government, district or city government, and private and community parties in integrated coastal area management planning in addition to this guidance also facilitates stakeholders in following the process and stages of coastal management planning in an integrated manner in accordance with the ecological, social and economic conditions of the communities in the coastal areas that are related and also standardize management planning mechanisms integrated coastal areas.

The social, economic and environmental knowledge related to the assessment of the main strategies through the Integrated Coastal and Marine Management program can be seen based on the results of the interview, it can be seen that there are efforts to improve the integration of programs in sustainable management of coastal and marine areas, including economic activities of fishermen who are supported by coaching so that integration can later reduce social conflicts in coastal and marine areas of Untia Village in addition there are also cooperation and coordination between sectors, including government, NGOs and the private sector through the Corporate Social Responsibility program.

Alternatives to developing coastal area development scenarios in Makassar City can be seen through the results of interviews, it can be seen that the decision support tools for testing scenarios Alternative strategies are prospective analyzes carried out to create a scenario for the development of urban coastal areas that are carried out sustainably in Makassar City in the future through factors key performance of integrated coastal area development systems. Of the various possibilities that occur, the development of the reclamation area begins with the preparation of complete documents such as the planned utilization of reclamation space, environmental impact analysis, environmental management plan, and environmental 
monitoring plan. The reclamation technique plan is formulated in three scenarios for developing the coastal area of Makassar City as an alternative to future activities. Based on the results of the interview it can be seen that there is a preparation of public consultation for coastal area development programs. Through this public consultation, there are mechanisms for community participation that can be adapted to public input and also stages of coastal area structuring activities.

Community participation mechanisms are carried out with community groups that can represent coastal areas and community organizations as well as professional organizations that can function as advocacy planning for the community. Can also be optimized community participation through workshop activities to accommodate input and criticism of the community can be an important record of the program. In addition, it can also be through verbal messages either directly or through the media to the executive and legislative parties that have authority and influence in the development of coastal areas. The attitude and behavior of the apparatus in accepting the need to develop effective organizational culture in public services [10].

Furthermore, the results of research on the development of the strategy of the Makassar city coastal area through the Governance Systems Analysis (GSA) framework emphasize the development of the strategy of the coastal city of Makassar, which researchers can review from the perspective of Governance Systems Analysis theory [9] in which there are variables specific about the development of strategies related to indicators of decision-making capacity, connectivity, and use of knowledge research results indicate that in the aspect of Decision Making Capacity there are various types of institutions that play a role in the Makassar North Reclamation area including the Ministry of Agrarian and Spatial Planning, Ministry of Public Works and Public Housing, City, Private, and community governments are also related institutions, namely the Department of Maritime Affairs and Fisheries of the South Sulawesi Province, the PSDA Office, South Sulawesi Province Cipta Karya and Spatial Planning, and Sula Province Regional Development Planning Agency (Bappeda) South Sulawesi.

Decision making capacity also sees stakeholders who have the knowledge, financial, human and infrastructure resources available to make the necessary decisions. There is a basis for planning that is outlined in the 2015-2034 RTRW of Makassar City, which outlines the objectives of urban spatial planning. The key institution involved in having strong organizational governance is the Regional Development Planning Agency (Bappeda) because it can make planning directed and systematic through the long-term and medium-term plans. The planning process has been carefully carried out in the regional sectoral development program arrangement that is inseparable from the development policies that have been announced in the Medium-Term Development Plan (RPJM) and the Long-Term Development Plan (RPJP). Furthermore, in terms of budget, there is funding from the Ministry of Maritime Affairs and Fisheries (KKP) which prepares the budget allocated for the improvement of the Nusantara Port Untia Makassar infrastructure, management of the budget until the physical auction process is carried out by the ministry. directives for controlling the utilization of city space. The existence of the RTRW that has been made with this BAPPEDA can be used as a guide for the implementation of development by utilizing space for development activities in the Makassar City area. In order for spatial utilization within the period of validity of the plan in accordance with the spatial plan, a control mechanism for spatial utilization is needed, such as the coastal area of Makassar City, control of spatial utilization is a provision intended as a spatial control tool [11].

Furthermore, in the aspect of connectivity shows that connectivity is aimed at both the main long-term programs whose actualization will be specified in the city's five-year midterm 
program which includes indications of the main program, funding sources, implementing agencies, construction sites, and implementation time structured in the indication of the embodiment program Structural plans, indications of programs embodied in plans for urban spatial patterns, and indications of program realization of strategic areas.

In the implementation of development, the main plan is prioritized in certain areas in meeting the needs of the people of Makassar City. Water catchment areas require protection to provide free space for the absorption of rainwater in certain areas to provide groundwater needs and flood mitigation.

In addition, it can be seen that there has been a significant increase in the use of vacant land for several years. This condition certainly has the potential to affect the depreciation or reduced area of water catchment centers in the Makassar City Region. The water catchment area in Makassar City is in the Balang Tonjong Lake Area in Manggala Subdistrict whose priority is now to become the main area. Although seen from the segment the role of the area is aimed at the water catchment area that can be optimized.

In addition, there is also segmentation of coastal borders in the city of Makassar, namely the area of mangrove forests whose objects are located in the northern sea coastal area or Untia Beach, this area is a natural habitat for mangrove forests which is useful to provide protection for the natural life of the ocean. Based on the data of mangrove forests located at the mouth of the river is a tidal area or the edge of the sea. For the direction of planning the coastal border area which is designated as a protected area is on the edge of the coast that stretches from the northern coastal area of the city to the western coastal areas of the city in Biringkanaya Subdistrict, Tamalanrea District, Tallo District, Ujung Tanah District, Ujung Pandang District, Wajo District, Mariso District, Tamalate District, and Sangkarrang Islands District. The beach border which is still natural and does not occur degradation is carried out by utilizing policies that certainly can conserve the area.

The connectivity in the effort to preserve the environment in the coastal city of Makassar, both the community and international institutions that collaborate in preserving the environment, especially the planting of mangroves in the coastal area of Untia. There are a number of issues concerning the degradation of coastal and coastal abrasion habitats, and the issue of the low quality of Fishery Product Processing, Capital Capability, and Bak Materials. Through a number of strategies to control the utilization of coastal and marine resources and the planned construction of wave-retaining embankments along the coast of the Bulo, strengthening public capital, regulations in the field of investment and providing investment incentives, improving skills and business management, fostering women fishermen, and optimizing land use.

Connectivity of coastal area conservation is carried out in various ways, namely through the construction of breakwaters to the coastal areas accompanied by reforestation through planting mangroves around the Tanjung Bunga beach area which can reduce the degree of coastal abrasion and subsequent efforts to conduct artificial reef activities as an effort to rehabilitate the marine environment. Nature has provided a coastal protection mechanism naturally and effectively through a sand beach whose sand stretch serves as a destroyer of wave energy effectively it must be a concern to improve the protection mechanism [12].

In the RTRW document, environmental conditions are explained, river boundaries are defined along the corridors of the Jeneberang River, Tallo River, and rivers within the Makassar City area. For existing conditions, the Tallo River has been heavily degraded. In general, the area around the border of this river has been converted into a residential area and business area, so the border space is increasingly narrow. The transfer of the function of the area is what causes environmental inconsistencies, because there have been many human 
interventions in it. It is different with the Jeneberang river which has environmental balance control. Along the Jeneberang border corridor can be found the use of land as an object of land use with the planting of ornamental plants. Through a series of research results found that the collaborative framework for goal setting designed to involve each party and the coastal area development strategy to integrate all problems with long-term solutions, this can be seen from connectivity in environmental conservation efforts in the coastal city of Makassar, both communities and institutions. international cooperation.

Connectivity is an important thing in Governance Systems Analysis (GSA) also aimed at both the main long-term programs whose actualization will be specified in the five-year medium-term program of the city which includes the main program indications, funding sources, implementing agencies, construction sites, and implementation time which is structured in the indication of the program embodiment of the structural plan, an indication of the program embodiment of the plan for the urban spatial pattern, and an indication of the program realization of the strategic area.

In the aspect of the use of knowledge which is part of the GSA Framework shows that there is a concept of Integrated Coastal and Marine Planning and Management (ICZPM) which provides guidance for the provincial government, district or city government, as well as private and community parties in integrated coastal area management planning, in addition, This guideline also facilitates the parties involved in following the process and stages of coastal management planning in an integrated manner in accordance with the ecological, social and economic conditions of the communities in the coastal areas that are related and also standardizes the mechanism for planning integrated coastal zone management.

Social, economic and environmental knowledge related to the assessment of the main strategies through the Integrated Coastal and Marine Management program is indicated by efforts to improve the integration of programs in sustainable management of coastal and marine areas, including economic activities of fishermen supported by coaching so that integration later it can reduce social conflicts in the coastal and marine areas of Untia Village, in addition, there are also cooperation and coordination between sectors, including government, NGOs and the private sector through the Corporate Social Responsibility program. Empowerment coastal communities and their implications for the development of coastal area management integrated means that must be considered in the development of coastal areas [13].

In addition to this empowerment, adaptive governance is needed to develop strategies of local governments in the development of an adaptive government region that can have an impact on the quality of governance [14]. Furthermore, there is a decision support tool for testing scenarios. An alternative strategy is a prospective analysis carried out to create a scenario for the development of urban coastal areas that are carried out sustainably in Makassar City in the future through key factors in the performance of integrated coastal area development systems. Of the various possibilities that occur, the development of the reclamation area begins with the preparation of complete documents such as the planned utilization of reclamation space, environmental impact analysis, environmental management plan, and environmental monitoring plan. The reclamation technique plan is formulated in three scenarios for developing the coastal area of Makassar City as an alternative to future activities.

The preparation of public involvement for coastal area development programs through public consultation has a mechanism for community participation that can be adapted to public input and also the stages of coastal area structuring activities. Community participation mechanisms are carried out with community groups that can represent coastal areas and 
community organizations as well as professional organizations that can function as advocacy planning for the community. Can also be optimized community participation through workshop activities to accommodate input and criticism of the community can be an important record of the program. In addition, it can also be through verbal messages either directly or through the media to the executive and legislative parties that have authority and influence in the development of coastal areas.

\section{Conclusion}

The development of the strategy of the Makassar city coastal area through the Governance Systems Analysis (GSA) framework shows that there is a well-planned planning process in the regional sectoral development program that is inseparable from the development policies that have been planned in the Medium-Term Development Plan (RPJM) and Development Plan Long-Term (RPJP). In order for spatial utilization within the period of time the plan is valid in accordance with the spatial plan, it is necessary to control the use of space such as the coastal area of Makassar City. connectivity in the effort to preserve the environment in the coastal city of Makassar, both the community and international institutions that collaborate in conserving the environment, especially the planting of mangroves in coastal areas. In the knowledge aspect, the preparation of public consultation for coastal area development programs. Through public consultation, there are mechanisms for community participation that can be adapted to public input and also the stages of coastal area structuring activities. Community participation mechanisms are carried out with community groups that can represent coastal areas and community organizations as well as professional organizations that can function as advocacy planning for the community.

\section{References}

[1] A. Hidayat, "Analisis Pengembangan Kawasan Pesisir Berbasis Mitigasi Sea Level Rise (Kenaikan Muka Air Laut) Studi Kasus Kawasan Kota Lama Makassar,” J. Lingkung. Binaan Indones., vol. 1, no. 1, pp. 87-100, 2012.

[2] W. S. Padang and H. K. Kusmanto, "Perencanaan Partisipatif Dalam Proses Penyusunan Rencana Pembangunan Jangka Menengah Daerah Kabupaten Dairi Tahun 2014-2019," Public Adm. J., vol. 5, no. 2, pp. 195-216, 2016.

[3] J. Sorensen, "National and international efforts at integrated coastal management: definitions, achievements, and lessons," Coast. Manag., vol. 25, no. 1, pp. 3-41, 1997.

[4] B. Cicin-Sain and S. Belfiore, "Linking marine protected areas to integrated coastal and ocean management: a review of theory and practice," Ocean Coast. Manag., vol. 48, no. 11, pp. 847-868, 2005.

[5] R. Kenchington and D. Crawford, "On the meaning of integration in coastal zone management," Ocean Coast. Manag., vol. 21, no. 1, pp. 109-127, 1993.

[6] M. Syukur, M. M. Tahir, and Z. Nahruddin, "Strategi Pemerintah Daerah Dalam Pengembangan Pasar Agribisnis Di Desa Sumillan Kecamatan Alla Kabupaten Enrekang," Otoritas J. Ilmu Pemerintah., vol. 2, no. 1, pp. 69-78, 2012.

[7] M. S. Hossain, "Biological aspects of the coastal and marine environment of Bangladesh," Ocean Coast. Manag., vol. 44, no. 3, pp. 261-282, 2001.

[8] M. D. Abror, "Governance Systems Analysis (GSA) Kerangka kerja untuk Mereformasi Sistem Pemerintahan,” J. Kebangs., vol. 5, no. 1, pp. 37-48, 2012.

[9] R. Potts and K. Vella, "Analysis of governance for sustainability planning in the 
Cairns Region," in State of Australian Cities National Conference, Gold Coast, Qld, 2015.

[10] Z. Nahruddin and H. Tambajong, "The Behavior of Apparatus and Cultural Organization in Provision of Public Service in District Level," Sch. J. Arts, Humanit. Soc. Sci., vol. 5, no. 7b, pp. 716-720, 2017.

[11] B. Koddeng, "Zonasi Kawasan Pesisir Pantai Makassar Berbasis Mitigasi Bencana (Studi Kasus Pantai Barambong-Celebes Convention Centre)," Res. Fac. Eng., vol. 5, pp. 4-20, 2011.

[12] R. Hartati, R. Pribadi, R. W. Astuti, and R. Yesiana, "Kajian Pengamanan Dan Perlindungan Pantai Di Wilayah Pesisir Kecamatan Tugu Dan Genuk, Kota Semarang," J. Kelaut. Trop., vol. 2, no. 19, pp. 9-110, 2016.

[13] V. Nikijuluw, "Populasi dan sosial ekonomi masyarakat pesisir serta strategi pemberdayaan mereka dalam konteks pengelolaan sumberdaya pesisir secara terpadu," in Bogor (ID): Pusat Kajian Sumberdaya pesisir dan lautan, Institut Pertanian Bogor, 2001.

[14] M. M. Tahir, Z. Nahruddin, and D. Ekawaty, “Adaptive Governance: Implementation of Green Open Space Program.” Official Publisher, 2016. 